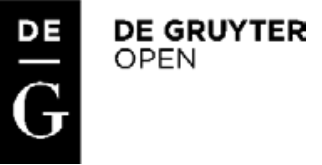

\title{
ELLIPSIS IN THE MACEDONIAN NOUN PHRASE
}

Blagojka Zdravkovska-Adamova, PhD

Language Centre, South East European University, Tetovo, R. Macedonia,

b.zdravkovska@seeu.edu.mk

DOI: 10.1515/seeur-2017-0019

\section{Abstract}

The aim of our paper is to present noun phrase ellipsis as a cohesive tie in the Macedonian language.

We will start our paper briefly discussing a few definitions of the term ellipsis, emphasizing our understanding of this term, and more concretely its meaning when occurring in the NP.

Namely, we define ellipsis as a complex phenomenon. In linguistics, it means the omitting of linguistic elements that need to be understood from the context, where the recipient should adequately fill the grammatically allowable gap. Then we will refer to different kinds of ellipsis in Macedonian, starting with our main issue ellipsis in the noun phrase.

Elliptical NP is cohesive and usually refers anaphorically to another NP. But the main question is how much of the full noun phrase is involved in the elliptical NP in Macedonian. For that purpose, we will analyze examples to define which elements of the NP can be omitted and under which conditions. Examples of cataphoric 
ellipsis are also included. When there is an ellipsis of the center of the phrase, the other element of the NP functions as the center of the phrase. For more precision research, we will use examples of different functional styles in Macedonian. The examples will be given first in Macedonian (M), and then translated into English (E).

Our conclusion will be presented through graphs.

Keywords: Ellipsis, noun phrase, Macedonian Language, endophora, exophora

\section{Definition of the term ellipsis}

Cohesion is one of the 7 criteria of textuality (Robert de Beaugrande \& Wolfgang Dressler, Introduction to text linguistics, 1981). Ellipsis is a cohesive tie (Halliday and Hasan, Cohesion in English, 1976) both in spoken and written texts and it is one of the most common cohesive ties in Macedonian.

Ellipsis (from the Greek word - elleipsis) means omitting. Ellipsis is a complex linguistic phenomenon which is marked in linguistics as an omission of linguistic elements that should be understood from the context, compelling the recipient to properly fill the grammatically allowable gap ${ }^{1}$, for which in the case of substitution, there is a substitute, and in the case of lexical cohesion, the same linguistic element or synonym will be used. Thus, people speak (write) elliptically without investing a lot of mental effort, and recipients also interpret elliptical sentences.

According to Halliday and Hasan (1976), the starting point in the definition of the term ellipsis is that there is "something left unsaid"2 (p. 142), but not in the sense that the unsaid is not understood, unclear. Quite the contrary, unsaid is understood.

\footnotetext{
${ }^{1}$ Greenbaum and Nelson determine the ellipsis as grammatical omission (Greenbaum, Nelson, 2009:166), although they stress that the distinction between grammatical omission and semantic implications is not always clear (Greenbaum, Nelson, 1999:111).

${ }^{2}$ It is a conscious omission of certain linguistic units.
} 
This means that the omitted element is missing at the surface of a sentence, but it is present in its meaning. Thus, our goal will be not only to determine which language elements can be omitted but also to determine the circumstances in which the ellipsis is mandatory or inappropriate.

When we are considering this cohesive tie, we do not think of any instance in which there is information that is not given and assume that the listener/reader should understand on the basis of knowledge from his experience, or to understand from the context. This practically means that all spoken and written sentences are included. The ellipsis is a reduction of a linguistic element, but we cannot define it just as a simple omission.

The stability of the text is established and maintained by the continuity of linguistic elements. The concept of continuity is based on the presupposition of the mentioned linguistic elements. In this regard, the determination of the ellipsis should emphasize the fact that it achieves this type of cohesive tie only when there is a presupposition about what is left unsaid. Therefore, on the sentence level, the ellipsis can best be explained by linking with the Functional Sentence Perspective, specifically with the theme. The theme is the part of the sentence which carries data known from the previous text or context. This means that in elliptical sentences, the theme can be discharged from the information that the sender thinks is known from the context or situation for the recipient of the text ${ }^{3}$, and thus does not leave space for ambiguity. Rhema is not discharged.

Similar to substitution, an ellipsis is a relation within a text. In most cases, the presupposed element is present in the preceding text. Thus, we can define ellipsis as an anaphoric relation, in that with this type of cohesive tie we refer back to the preceding text.

\footnotetext{
${ }^{3}$ Although the interpretation of the sentence depends not only on the content of the sentence, but also from the recipient of the text.
} 
[1M] Околу нас во мочуриштето се движеле во потрага по живот водни глувии, водни змии и водни желки. Не ретко и видри. (СЈ, ДКВ)

[1E] Around us, in search of a life, water rats, snakes and turtles were moving in the swamp. Otters were infrequently doing ${ }^{4}$ that as well.

When we have anaphoric ellipsis, the omitted item is usually in the preceding sentence, and rarely in other previous sentences, as in the following example:

[2M] Тој го отворил едното око. Златна пеперуга го покрила небото...

Го отворил другото. (СЈ, ДКВ)

[2E] He opened one eye. Golden butterfly covered the sky... He opened the other.

Occasionally the omitted item in an elliptical structure may be provided subsequently (cataphoric relation) as in the following example:

[3М] Наслушнувал и чекал да се брани и да се одбрани со меч во десната и нож во левата рака. (= ...да се одбрани со меч во десната рака...) (СЈ, ДКВ)

[3E] He heard and waited to protect and defend himself with a sword in his right and a knife in his left hand (= ... to defend himself with a sword in his right hand...)

Anaphoric and cataphoric ellipsis are determined as a certain kind of a textual ellipsis. However, the omitted item can be specified from a situation, and thus we have an exophoric relation. For example, if we say to a seller of roses:

[4М] Ве молам, три.

[4E] Three, please.

\footnotetext{
${ }^{4}$ It is impossible to translate this example with ellipsis into English as it is in Macedonian (as cohesively as the other examples). In English, we have substitution, and this cohesive tie is not so common in Macedonian.
} 
In that case, we have exophoric ellipsis. A situational context is the one that provides the necessary information to interpret the statement. According to Halliday and Hasan (1976), an exophoric ellipsis is not associated with cohesion, because "it does not contribute directly to cohesion as we have defined it” (p.37).

Moreover, if the omission of linguistic elements is within endophora then it is a contextual ellipsis. Situational ellipsis is associated with exophora.

As for the ellipsis and substitution, normally the syntactic structure has no limit. Both cohesive ties are considered to be a relation between sentences, as well as relational within sentences.

Take, for example, the following complex sentence (two structurally related clauses):

[5М] Русијан изгуби двајйа воини, селото двајцุа жители. (СЈ, КР)

[5E] Rusijan lost two warriors, the village two inhabitants.

At the syntactic level, the structure of the second clause consists of the subject and direct object. This structure only occurs in sentences in which at least one linguistic element, which is the predicate, is presupposed. So to get the full structure of this sentence, the gap should be supplemented by a predicate, and in this instance, it can only be the predicate of the first clause. We say only, because there is no other alternative interpretation in this case, and the second sentence could be identified only as: ... селото изгуби двајиа воини (... the village lost two inhabitants).

In our research, when we talk about ellipsis we refer specifically to a word or phrase, clauses or sentences, whose structure suggests the existence of a previous element, which serves as a source for the missing information. The elliptical language element leaves a specific structural gap that can be filled from elsewhere in the text.

This is present in the next example: 
[6М] Имам јас синови и имам од нив внуичи. Од двајцата. Есенва ќе го оженам и третиот. И Геро Слез израсна и созреа. Силен е, ке му најдам две жени. Трета самиот ќе си најде. (СЈ, ДКВ)

[6E] I have sons and I have grandchildren. From both. This autumn I will marry the third. And Gero Slez grew up and matured. He is strong; I will find two women for him. He will find the third one by himself.

The second sentence contains a noun phrase dвajugama ${ }^{5}$ (both). To be complete, the noun phrase should complement the noun from the previous sentence, in this case синови (sons). This means that if the noun phrase occurs only with a modifier, in this case number, or numerical adjectives ${ }^{6}$ (as mpemuom (the third), for example), it yields an elliptical NP whose center should be determined from the context.

The examples above show that where there is an ellipsis, there is a presupposition that something unsaid is understood. Respectively, we say that one element is elliptical if within its structure all segments contributing to its shaping are not represented - all the meanings are achieved with this structure.

Generally, there is an ellipsis when there is something necessary to complete the structure (to have a full and proper grammatical structure) that is actually missing, so a sense of incompleteness appears in the structure, but there is no semantic incompleteness. The main function of the ellipsis is to achieve an economy of language expressions by avoiding repetition. It contributes to clarity and emphasis; that is, through this cohesive tie, it is enabled to highlight only new and important information (which is the reason why ellipsis is connected with the theme and rheme in Functional Sentence Perspective).

\footnotetext{
${ }^{5}$ In Macedonian, there are specific forms of numbers for people.

${ }^{6}$ In Macedonian, ordinal numbers are included in a group named numerical adjectives.
} 
Since it sometimes is difficult to determine the boundaries of the ellipsis as a conclusion for this section, the five criteria for determining the ellipsis from Quirk will be listed (Quirk cited in Yamamoto, 1999:90). They are as follows:

a. The ellipted element is precisely recoverable.

b. The elliptical construction is grammatically "defective“.

c. The insertion of the missing expression results in grammatical sentences (with the same meaning as the original, elliptical sentence).

$\mathrm{d}$. The missing word(s) is (are) textually recoverable, and

e. Is (are) present in the text in exactly the same form.

\section{Types of ellipsis}

The term ellipsis is used to refer to the diversity of this cohesive tie. In general, we separate ellipsis into the following three types:

Syntactic ellipsis ${ }^{7}$ marks the incompleteness of the surface structure. This type of ellipsis covers examples in which mandatory language elements for syntactically complete sentences are omitted (predicates, for example), but under strict conditions relating to the form and consistency of interpretation.

Semantic ellipsis means the omitting of syntactic elements that are not mandatory (modifiers in the noun phrases, for example), but are required to complete semantic interpretations of the text.

Pragmatic ellipsis is about the incompleteness of interpretation, which is determined according to the general principles of pragmatic interpretation.

There is another division that is based on the determination of the omitted linguistic element in the following ways:

${ }^{7}$ Thus indicated by Merchant (2007:1) and other authors as linguistic (Neale, 2005:188). 
- Determination within the text (omitted element is within the text);

- Situational determination (full form is determined by extra-linguistic factors or by situation);

- Structural determination (form is determined by the grammatical structure). Our research is based on the following classification of the ellipsis:

- Nominal ellipsis

- Verbal ellipsis

- Clause ellipsis

And as we already stressed, in our paper we will analyze ellipsis in the nominal phrase in Macedonian.

\section{Ellipsis in the nominal phrase (nominal ellipsis)}

\section{Definition of the term nominal ellipsis}

Nominal ellipsis refers to ellipsis within the noun phrase or to ellipsis of the whole noun phrase, as in the following example:

[7М] На едни светции им носеа подароци, на други им ветуваа.

$$
\text { (= ...на други им ветуваа подароци.) (ПА, Т) }
$$

[7E] To some saints, they would give gifts, whereas to others they would promise (them) (= ... for the others they promised gifts.)

When there is an ellipsis in the center of the NP, the other element of the phrase takes functions as the center of the phrase.

Prior to dwelling on the nominal ellipsis, we will enumerate modifiers that may occur in the NP in Macedonian (Минова, 1994:106).

\section{a) Premodifiers}

- auxiliary determiners, e.g.: cume (all); 
- determiners, e.g.: deme-mo (the child), oва deme (this child), едно deme (one child);

- numbers, numerical adjectives, quantifiers, e.g.: три (three), петмина (five pеорle), неколку (several);

- adjectives:

- possessive adjectives and possessive pronouns ${ }^{8}$, e.g.: $\operatorname{moj}$ (my, mine), ваши (your, yours)

- ordinal numbers, e.g.: вmop (second)

- descriptive adjectives, e.g.: убава (beautiful)

- relative adjectives ${ }^{9}$, e.g.: памучен (cottony)

\section{b) Postmodifiers}

- other dependent noun phrases, e.g.: од моите гости (from my guests)

- dependent clauses, e.g.: кои ме прамуваa ( who asked me)

The determiners are linguistic elements that signal referential characteristics of the noun phrase. With numbers and numerical adjectives, we give information about the quantity of counted elements represented by the noun phrase and the quantifiers, based on the subjective perception of the speakers. With the adjectives, we give the particular characteristics of the objects, persons, etc. Some of these elements can occur multiple times in a single NP.

The center of the phrase is represented by a proper noun, common noun or pronoun. In non-elliptical noun phrases, the center of the phrase is a noun referring to an individual item or class that represents that element. The center of the phrase may be all that is covered by the definition of the term noun. Personal pronouns and

\footnotetext{
${ }^{8}$ In Macedonian, possessive pronouns and ordinal numbers are included in the group of adjectives since they have the same grammatical characteristics as other adjectives in terms of gender and number.

${ }^{9}$ In Macedonian, we differentiate types of adjectives - relative adjectives - which are connected with origin, material, etc. For example: (француски (French), татков (father’s).
} 
proper nouns can only occasionally be accompanied by a modifier (Убавата maa на баба (Grandma's lovely one);Високиот Горан те бараме (You were sought after by Goran, the Tall.). On the other hand, common nouns are often subsequently determined precisely by determiners, numbers, adjectives.

When the common nouns are omitted, the function center of the phrase is appropriated by any of the modifiers and then the determiner (except the definite article which is not an independent morpheme in Macedonian), number, or adjective functions as the center of the phrase.

[8М] Герман дочекал една внучка, Милена две. (СЈ, ДКВ)

[8E] German was blessed with one granddaughter, Milena two.

Thus, we can conclude that every noun phrase in which one of the modifiers functions as the center of the phrase is an elliptical noun phrase. This means that nominal ellipsis is actually upgrading the word that in the full noun phrase is a modifier, and in the elliptical one receives the function of the center of the phrase. So from the status of modifier, it achieves the status of the center of the NP.

The elliptical noun phrase clearly shows that there is information that can come through an available source, which is needed to supplement the noun phrase and therefore becomes complete. An elliptical noun phrase suggests that there is another noun phrase which is not elliptical and is, therefore, cohesive. 


\section{Presupposition on nominal elements}

The elliptical NP is cohesive and usually leads anaphorically to another NP. But the question is how much of the full noun phrase is involved in the elliptical one.

In the following example [9], the center is omitted in the elliptical NP. But there are other elements (modifiers) that also do not appear in the elliptical NP.

[9М] Сакам да ти ги покажам овие мои два бели свилени шалови. ${ }^{10}$ Можам да ти дадам еден ако сакаш.

[9E] I want to show you these two white silk scarves of mine. I can give you one if you want.

In this example, еден (оne) does not only refer to the noun шал (scarf) but also to the additional explanations: овој (this), мој (тіпе), бел (white) and свилен (silky). This means that the elliptical NP may be supplemented, so we get the following NP: еден бел свилен шал (оne white silk scarf), or еден мој бел свилен шал (one white silk scarf of mine). We may determine what can be presupposed by referring to the structure of the NP, or by structural elements: demonstratives (D), numbers $(\mathrm{N})$, and adjectives (A).

For better illustration of the previous example, we will consider the following sentences:

[10М] Сакам да ти ги покажам овие мои два бели свилени

иалови.

a. Kaде се mвоите?

б. Јас имав три.

в. Гледаш некој ирн?

д. Или повеќ сакаш памучен?

\footnotetext{
${ }^{10}$ Although in this example it is better for the noun to be in the dual form (два шала-two scarves). In an effort to more clearly explain the examples that follow, the noun is given in ordinary plural form.
} 


\section{[10E] I want to show you these two white silk scarves of mine ${ }^{11}$.}

a. Where are yours?

b. I had three.

c. Do you see a black one?

d. Or would you prefer cotton?

In the example [10 a.] mвoume (yours) is the center of the noun phrase and presupposed elements can not only relate to the noun шалови (scarves), but also to бели (white), свилени (silk) and possibly два (two).

In the following example [10 b.] mpu (three) is the center of the NP. Here, unlike the previous example, there is a restriction on the omitted elements. The plural form шалови (scarves) is mandatory to complement the whole noun phrase, and бели (white) и свилени (silk) can occur. The number два (two) can never be part of this elliptical NP because we already have three. In this example, the possessive pronoun мou (mine) would be redundant because the information for possession is given by the verb in Macedonian: имав (I have), so rarely would we find such examples: Имав три мои (бели, свилени) шалови [I had three (white silk) scarves of mine].

In the example below, c. [10 c.] in the elliptical NP некој ирн (a black one), the center of the phrase is a descriptive adjective: ирн (black), and шал (scarf) and свилен (silky) are missing. The singular form of the adjective in Macedonian limits the use of the number. If the example is: Гледаш некои ирни? (Do уои see any black ones?), then there may be a number: Гледаш некои два ирни (Do уои see any two black ones?). Scarves, however, cannot be mine: Дали гледаш твој ирн? (Dо уои see your black one?).

\footnotetext{
${ }^{11}$ In our paper we are using a similar example to that given by Halliday and Hasan (1976:150) because it will be easier to compare Macedonian and English.
} 
In the last example (10 d.), the presupposed noun is шал (scarf), which might be white. Also, in this example, the limit to the number is given by the singular form of the adjective in Macedonian .

According to what has been discussed, we can consider the following table:

\begin{tabular}{|l|l|l|}
\hline $\begin{array}{c}\text { If instead of the center of } \\
\text { the NP there is: }\end{array}$ & \multicolumn{1}{|c|}{ Omitted: } & $\begin{array}{c}\text { Might be } \\
\text { presupposed: }\end{array}$ \\
\hline Demonstrative (D) & The center of the NP & A, N \\
\hline Number (N) & The center of the NP & A, D \\
\hline Adjective (A) & The center of the NP & N, D, A* \\
\hline
\end{tabular}

* Which adjective might be presupposed depends on the type of adjective at the center of the elliptical noun phrase.

From the examples above, it can be concluded that the emergence of the new determiners in the elliptical NP may affect the rejection of some modifiers of the full NP. Overall, the possible presumptions mainly depend on the structure of the specific NP.

\section{Types of nominal ellipsis}

In more detail, we will look at examples of the most common types of nominal ellipsis.

\section{Determiners}

In non-gestural communication, we can identify something or someone with linguistic elements. In terms of determination, we think primarily of demonstrative pronouns and definite articles, specifically, еден (оnе) in Macedonian as an indefinite article and other determiners in Macedonian (indefinite, interrogative, negative pronouns, etc.). 
We distinguish determinators that indicate whether the object is definite or indefinite, and auxiliary determiners that can be used together with the basic determiners.

The demonstrative pronouns овој, оној (this, that) are often at the center of the elliptical NP and are used in anaphoric ellipsis.

[11M] Ние не сме далеку ни од Кукулино ни од sвездите. Погледни од онаа ќе падне крв. (СЈ, КР)

[11E] We are not far, neither from Kukulino nor from the stars. Look, that one ${ }^{12}$ will release blood. (... that star)

\section{Numbers and quantifiers ${ }^{13}$}

From the elements that occur after determiners in the NP, numbers and adjectives can function as a center in the elliptical NP.

Numbers in the elliptical NP

We often find cardinal numbers in elliptical forms, as in the following example:

[12М] Ноќи, помеѓу две - еден ден. Достатно. (СЈ, ДКВ)

[12E] Nights, between the two - one day. Sufficiently.

If in the elliptical NP, the center of the phrase is the number $2(\partial в a / t w o)$ or any other number, the full phrase can only be a noun in the singular (without any number), as in the following examples:

[13М] Кренеш ли меч ќе налеташ на два. (СЈ,КР)

[13E] If you raise a sword, you will be confronted with two.

\footnotetext{
${ }^{12}$ As we mentioned before, and as we can see from the examples, very often we have ellipsis in Macedonian, where in English we have substitution.

${ }^{13}$ Examples with the numerical adjective (ordinal numbers) are considered below.
} 
An elliptical NP with a number may be complemented with a determiner suitable for numbers, such as mpume (the three), овие три (these three), секои три (every three), or cume mpu (all three).

[14M] И подоџна, веке со жена и со деца, три и сите женски, како што и брат му Саве имал три, сите машки... (= ...и сите три женски, ... сите три машки...) (СЈ, ДКВ)

[14E] And later, already with a wife and children, three, and all female, as his brother Save had three, all male ... (= ... and all three female ... all three male ...)

Usually before proper nouns numbers don't occur, so rarely do we find examples in which elliptical NP is a proper noun, except in the following:

[15М] Вчера ја видов едната Ана, а денеска другата. И двете ме поздравија. (= И двете Ани ... )

[15E] Yesterday I saw one Anna, and today the other. Both greeted me. (= Both Anas...)

And обата/обајцата ${ }^{14}$ (both) often function as elliptical. Anaphorically refers to another NP in plural, or two or more singular NPs. The following example can be presented with NP in plural [16 a.] or with two noun phrases in singular [16 b.]

[16М] а. Родителите се вратија на полноќ. Обајцата беа изморени.

\section{б. Мајката и таткото се вратија на полноќ. Обајцата} беа изморени

[16E] a. The parents returned at midnight. They were both tired.

$b$. The mother and the father returned at midnight. They were both tired.

\footnotetext{
${ }^{14}$ In Macedonian we can use oбajuama only before nouns that denominate people.
} 
This means that oбajuama (both) can refer to two separate NPs, which could be in the same sentence [16 b.], or in different sentences, as in the following example:

[17М] Петар учеше до доичн. Марија иела ноќ размислуваше за патувањето. Утрото обајцата беа исирпени.

[17E] Peter studied until late. Mary was thinking about the trip all night. In the morning they were both exhausted.

\section{Quantifiers}

Quantifiers, for example, многу, малку, неколку, неколкумина (much, few, several, etc.), and other words with numerative function are often used with an ellipsis.

[18М] Митре: Колку години имаш? (РК, ПО)

Анѓеле: Еее... триесет и неколку.

[18E] Mitre: How old are you?

Angele: Well ... Thirty-something.

\section{Adjectives}

All types of adjectives can occur as a center of an elliptical NP:

\section{Possessive adjectives}

In the following examples, the center of an elliptical NP is a possessive adjective. Usually, the number of a noun corresponds to the number of a possessive adjective.

[19M] Зафир Ут не им стоел на пат. Ни тие на неговиот. (СЈ, Ч)

[19E] Zafir Ut did not stand in their way. Neither had they stood in his.

Rarely do we come across examples of a noun or possessive adjective which doesn't correspond, in terms of grammatical category, to number in Macedonian: 
[20М] Секаде има граници, но нашата е малку подалеку. ${ }^{15}$ (ПА, T)

[20E] There are borders everywhere, but ours is a little further.

Apart from the center of the NP, an elliptical NP represented by a possessive adjective can refer to other types of adjectives, but never to other possessive adjectives.

[21M] Како и да е: секој човек си е посебна приказна. А мојата, постојано, некој ја растура. (= A мојата посебна приказна...) (ПА, Т)

[21E] However, each person has a special story. And mine, always, is being spoiled. (= And my special story...)

Rare are the examples in which elliptical NP occurs before the full noun phrase, i.e. cataphoric ellipsis, as in the following example:

[22М] ...се плачело на свој, се плачело и над туѓ мртовец. (СЈ, Ч)

[22E] ...our own and other people's deceased were mourned.

Numerical adjectives (ordinal numbers)

Ordinal numbers are often used elliptically. They themselves indicate the existence of another NP even when they are part of an NP that is not elliptical, as in the following example:

[23М] Со вториот модел „Пола учество “ државата ќе плати 50 отсто од учеството за кредитот. (Вест)

[23E] The second model "Half Participation" means that the state will pay 50 percent of the loan.

\footnotetext{
${ }^{15}$ In this example the noun is in plural and the elliptical NP is represented by a possessive adjective in singular form.
} 
In this case, the noun phrase вториот модел (the second model) suggests that there is another first model. Or, if you say the first model it means that there is another model or perhaps some other models.

Because of this, NPs with ordinal numbers are similar to the comparative and superlative forms, which also indicate the existence of other NP.

However, previous ordinal numbers do not always occur in the context, as in the following example:

[24M] Најпрвин тоа бил густ зовриен облак со застрашувачки шум во себе-еден, потоа уште еден и, пак, по нив трет, три страшни облака од кои и сонцето се затемнело. (= ... по нив трет облак...) (СЈ, Ч)

[24E] First it was a thick boiling cloud with a frightening noise in itself -one, then another and again, followed by a third, three awesome clouds from which the sun went dark. (= ... followed by a third cloud...)

In this example [24], we didn't find previous ordinal numbers (first, second) but the ordinal number mpem (third) indicates the existence of the other two clouds.

In the next example [25], the first and second roosters are not mentioned in the context, yet the noun phrase mретите петли (third roosters) suggests their existence:

[25M] Само пред третите петли се повлекувале во тој Век први. (СЈ, ДКВ)

[25E] Only before the third crowing of the roosters did they withdraw in that first century.

The elliptical NP which operates as a center generally takes the definite article, anaphorically referring to another NP: 
[26М] Сега гледам дека е најтешко да се направи првиот и решителен чекор. Вториот е веќ полесен. (ПА, Т)

[26E] Now I see that it is most difficult to make the first and decisive step. The second (one) is already easier.

Only in certain instances in which there is a generic use of the NP, the ordinal number (which is the center of an elliptical NP) is without the definite article:

[27M] И Геро Слез израсна и созреа. Силен е, ќе му најдам две жени. Трета самиот ќе си најде. (СЈ, ДКВ)

[27E] And Gero Sles has grown and matured. He is strong; I will find two women for him. He will find the third (one) ${ }^{16}$.

If other modifiers occur within an NP with ordinal numbers, the elliptical NP with an ordinal number as the center of the phrase applies to the other types of adjectives, numbers, etc., but never to another ordinal number.

The NP вториот најголем сопственик (second largest owner) in the following example [28] don't refer only to the existence of the first owner, but also indicates the existence of the first largest owner.

[28M] Јапонија е вториот најголем сопственик на монетарни обврзниции во светот по Кина (Вест)

[28E] Japan is the second largest owner of a monetary bond in the world after China.

In the next example [29], the elliptical NP првиот (first), except that it excludes the ordinal number of the second full NP, covers all other modifiers and the center of the phrase, i.e. premodifier: европски (European); the center: план (plan); and postmodifier: за финансиска помош на земјата (for financial assistance to the country).

\footnotetext{
${ }^{16}$ In this example a substitution is more suitable in English, but not in Macedonian.
} 
[29M] Прелиминарните разговори беа организирани по изненадувачката одлука на грчкиот премиер во понеделникот да распише референдум за вториот европски план за финансиска помош на земјата.

Двете пратенички беа против одлуката на премиерот и за првиот. (Вест)

[29E] Preliminary talks were held after the surprise decision by the Greek Prime Minister on Monday to call a referendum on the second European plan for financial assistance to the country. The two MPs were against that decision of the prime minister and also the first.

\section{Descriptive adjectives}

When the center of the NP is a descriptive adjective, it refers only to the center of the full NP, for example:

[30М] На гуштерищата искуби иे опаш, за ден или два, можеби за пет, ќe ѝ израсне нов. (СJ, КР)

[30E] The lizard whose tail you tugged off, in a day or two, maybe five, will grow a new one.

It is common for other elliptical NPs, which have as a center function other descriptive adjectives, to occur consecutively. In the following example, an elliptical NP нова (nеw), is followed by another elliptical NP, or поголема (greater).

[31М] Црквичкава ни е кочница, дедо попе. За пчели. А погледни што народ се крсти во Кукулино. Да построиме нова и поголема, со шарен олтар? (СЈ, Ч)

[31E] The church is our basket, Father. For bees. A look at which people are baptized in Kuklino. Should we build one newer and larger, with a colorful altar? 
This elliptical NP can be extended with the other adjectives that occur in the full NP, as in the example [32]:

[32М] А Игор има толку убави и мили очи. Длабоки и темни, небаре плодови од презреан боз. (ПА, Т)

[32E] And Igor has such beautiful and kind eyes. Deep and dark, like ripe fruit from elderberry.

This means that the full NP, except the center ( очu - eyes), will include the adjectives убави и мили (beautiful and kind), so the full NP will be: длабоки, темни, убави и мили очи (deep, dark, beautiful and kind eyes).

As ordinal numbers, comparative and superlative forms indicate the existence of other phrases with the same noun as the center of the NP. If the center of the elliptical $\mathrm{NP}$ is in comparative or superlative form, this always indicates the existence of other noun phrases, which are not always explicit:

[33М] Имала три сестри, не и брат, секоја на своја страна и со своја среќa. Најстарата невенчана, во градска куќа ...(СЈ, ДКВ)

[33E] She had three sisters and no brother, each on their own path and with their own happiness. The oldest (one) unmarried, in the town house...

In the following examples in which the center of the elliptical NP is a descriptive adjective, we can determine that it is exophoric ellipsis or a substantivised adjective:

[34M] а. Сиромавиот двапати плаќа.

б. Добриот и будалиот се исто.

в. Паметниот запишува, будалиот памти.
[34E] a. The poor (man) pays twice.

$b$. The good and the fool are the same.

c. The smart writes, the fool

remembers.

Relative adjectives

Also, a relative adjective can be the center of the elliptical NP: 
[35М] Зад двоколката чекорела без солзи Дарија Исова со своите пет деца, две машки и три женски, шестото било во неа. (СЈ, ДКВ)

[35E] Behind the chariot, Daria Isova walked without tears with her five children, two male and three female, and a sixth on the way. In this example [36] the two elliptical NPs are presented with a number and relative adjective.

The following example illustrates separate instances in which there is one center and two modifiers:

[36М] Семинарот се претвори во дискусија за разликите меѓу европската и американската кошарка ... (УВ)

[36E] The seminar turned into a discussion about the differences between European and American basketball ...

Here we see that two NPs (европската кошарка и американската кошаркаEuropean and American basketball ...) are accepted as coordinated groups.

Cataphora is rare:

[37М] Досието за казната на Победа е пренесено од европската фудбалска на македонската политичка сцена. (Вест)

[37E] The file about the penalty of Pobeda has been transferred from European football to the Macedonian political scene.

\section{Conclusion}

A text is a feature of modern linguistic studies. In doing so, cohesion and cohesive ties are one of the central issues. Through the analysis of cohesion, the semantic and grammatical connections in the text between the sentences and the parts in the text come to mind.

In our research, we retain the ellipse in the noun phrase, which, like other types of ellipses, leads to the economy of language expression. The text recipient can focus 
on the more important parts of the text. The whole answer, unless it is in the direction of emphasis, seems unnecessarily extensive, redundant and unnatural.

The analysis of the examples in Macedonian indicates that this cohesive link is very important for the shaping of the texts. Our research has been done on the basis of texts from different functional styles, but most of the examples are from the literature.

Moreover, in the scientific, administrative, and in the publicist functional style, the use of this cohesive link is much more limited, compared with conversational and literary style. Therefore, most of the examples in our research are from the literature. 


\section{Ellipsis of the premodifier.}

екстот на песната ме инспирираше да направам ваков спот. Спотот беше промовиран во скопското кафуле Драма. (Вест)

Lyrics inspired me to make this video. The video was promoted in the Skopje cafe Drama.

\section{Ellipsis of the centre of the NP. Modifier functions as centre of the}

Demonstratives: Ги знаеш какви се жениве наши: „Оваа била ваква - онаа била онаква! (РК, ПО)

You know our women: She was like this....the other was like that!

\section{Ellipsis}

In the NP

Number: Герман дочекал една внучка, Милена две. (СЈ, ДКВ)

German was blessed with one granddaughter, Milena two.

Adjective: Ḱе излажам ако скријам дека и мојот живот не ме потсетува на нивниот. (ПА, Т)

I would be lying if I hid that my life reminds me of their own.

\section{Ellipsis of the postmodifier.}

Dependent NP: Преговорите за името продолжуваат. Hие очекуваме во иднина преговорите да донесат резултати. (Сител)

Negotiations for the name are continuing. We expect the future negotiations to bear fruit.

Dependent clause: Договорот кој беше постигнат не беше почитуван и од двете страни и покрај тоа што договорот беше прифратен од двете страни. (Телма)

The agreement that was reached was not respected by either side despite the fact that the agreement was accepted by both sides. 


\section{References}

\section{Latin alphabet}

- De Beaugrande, R., Dressler, W. (1981). Introduction to text linguistics. Longman Inc, New York

- Greenbaum, S., Nelson, G. (1999). Elliptical clauses in spoken and written English in The clause in English: In Honor of Rodney Huddleston (Peter Collins and David Lee - Eds.)

- Greenbaum, S., Nelson, G. (2009). An Introduction to English Grammar. Pearson Education Limited

- Haliday, M.A.K., Hasan, R. (1976). Cohesion in English. Longman

- Merchant, J. (2007). Three kinds of ellipsis: Syntactic, semantic, pragmatic?, Semantics workshop, Rutgers

- file://C:/Users/b.zdravkovska/Downloads/merchant_07_Three-kindso.pdf

- $\quad$ Neale, S. (2005). Pragmatism and Binding in Szabo, Z.G. (editor). Semantics versus Pragmatics. Oxford University Press

- Yamamoto, M. (1999). Animacy and Reference: A Cognitive Approach to Corpus Linguistics. John Benjamin Publishing Company

Cyrillic alphabet

- Дучевска, А (2005). Анализа на текстот и дискурсот во македонскиот јазик (докторска дисертација). Филолошки факултет „Блаже Конески“- Скопје

- Минова-Гууркова, Л. (1994). Синтакса на македонскиот стандарден јазик. Радинг, Скопје 


\section{Examples}

\section{Literature:}

- Петре Андреевски, Тунел - (ПА,Т)

- Ристо Крле, Парите се отепувачка - (РК, ПО)

- Славко Јаневски, Девет керубинови векови - (СЈ, ДКВ)

- Славко Јаневски, Кучешко распетие - (СЈ, КР)

- Славко Јаневски, Чудотворци - (СЈ, Ч)

\section{Media}

- Вест - (Вест)

- Утрински весник - (УВ)

- Сител - (Сител)

- Телма-(Телма) 